\title{
Combustion Characteristics of Cottonseed Biodiesel and Chicken Fat Biodiesel Mixture in a Multi-Cylinder Compression Ignition Engine
}

\author{
K. Masera and A. K. Hossain \\ Aston University, UK
}

\begin{abstract}
Although waste animal fats such as chicken fat are promising alternative energy sources, biodiesels produced from these type of feedstocks hardly satisfies the EN14214 biodiesel standards. In this study, biomixtures were prepared by blending cottonseed biodiesel and chicken rendering fat biodiesel which were produced via transesterification method. Biodiesels were blended with each other at $60 / 40,50 / 50$ and $30 / 70$ volume ratios to produce $\mathrm{CO} 60 \mathrm{CH} 40$, $\mathrm{CO} 50 \mathrm{CH} 50$ and $\mathrm{CO} 30 \mathrm{CH} 70$ fuels. First, fuel properties of the neat biodiesels and novel biomixtures were measured and compared to European biodiesel standards and diesel. Then, the engine performance, combustion characteristics and exhaust emissions of these novel biomixture fuels were measured in a three-cylinder indirect injection diesel engine under various engine loads and at constant speed of $1500 \mathrm{rpm}$. The fuel characterisation showed that $\mathrm{CO} 60 \mathrm{CH} 40$ and $\mathrm{CO} 50 \mathrm{CH} 50$ biomixtures met the European standards. The Brake Specific Energy Consumption (BSEC) and Brake Thermal Efficiency (BTE) of all biomixtures were comparable with $\mathrm{CO} 100, \mathrm{CH} 100$ and diesel at the full engine load. The combustion results revealed that the maximum in-cylinder pressure and energy release values of the CO50CH50 were $4.2 \%$ and $4.4 \%$ higher than the diesel at full engine load because of optimised fuel properties of biomixture such as molecular structure, viscosity, cetane number and iodine value. $\mathrm{CO} 50 \mathrm{CH} 50$ had $2.9 \%$ reduced $\mathrm{CO}_{2}$ and comparable $\mathrm{CO}$ emission compared to diesel, which were also $5.6 \%$ and $13 \%$ lower than cottonseed biodiesel respectively. However, NO emission of $\mathrm{CO} 50 \mathrm{CH} 50$ was found $3.8 \%$ and $5.8 \%$ higher than diesel and cottonseed biodiesel. A $6.5 \%$ reduction on $\mathrm{NO}$ emission was observed when $\mathrm{CO} 60 \mathrm{CH} 40$ biomixture fuel was used instead of diesel. To conclude, this research showed that blending of cottonseed and chicken fat biodiesels is a promising approach to meet the EN14214 standards, improve in-cylinder pressure, optimise energy release and reduce exhaust emissions. Blending of different biodiesels will be tested as a future work.
\end{abstract}

\section{Introduction}

Energy demand is increasing due to population growth and high standards of living [1]. Due to limited fossil fuel resources, the refinery capacity and strict carbon emission regulations, the need for alternative energy is increasing considerably. According to the International Energy Agency, two-thirds of overall greenhouse gas emissions and more specifically $80 \%$ of the $\mathrm{CO}_{2}$ emission is accounted for the energy sector [2]. Many sustainable solutions studied to provide renewable energy like solar, wind, geothermal, wave, etc. [3]. Like all other renewables, biofuels are also important as they can be used for different applications such as electricity production, heating and transport [4]. The European Union encourages the utilisation of biofuels as member countries have to satisfy $10 \%$ renewable requirement for transportation fuel by 2020 [5]. Researchers investigated various biofuels like neat vegetable oils, pyrolysis oils, emulsified fuels and biodiesels [6]. Among the various biofuels, biodiesel occupies the bigger portion of the renewable energy supply. According to the UK Department for Transport, biodiesel shared $47 \%$ of the renewable fuel supply in 2018 [7]. Its inherent fuel properties, biodegradability, being carbon neutral, environmentally friendly and applicability to diesel engines without any major modifications make biodiesel a viable alternative fuel [8].

Biodiesel can be produced from a large variety of organic compounds such as plant oils, waste cooking oils, waste animal fats and algae [911]. Waste animal fats started to gain more attention from the researchers in the last decade due to their cheap cost and high availability [12]. Moreover, as they are waste materials, their disposal is subjected to some procedures in the UK [13]. High availability of waste chicken was reported as 86 million chickens in the UK in 2015, which makes the feedstock very attractive for the biodiesel production [14]. The waste chicken feedstocks may involve chicken trims, offal, blood, feathers and skin [15]. The feedstock is exposed to the rendering process to extract the chicken fat [12]. Depending on the type and quality of the rendered fat, a pretreatment process may be needed. Alptekin and Canakci [16] reported that any feedstock having Free Fatty Acid (FFA) level above the 1\% should be pretreated prior to the transesterification process. Apart from conventional transesterification techniques, Marulanda et al [17] investigated the supercritical transesterification of chicken fat at 300$400{ }^{\circ} \mathrm{C}$ temperatures and up to $41.1 \mathrm{MPa}$ pressures. They addressed that this technique had potential to provide cheaper continuous production of a biodiesel as the glycerol (a by-product of the transesterification) also decomposes under the high temperature and pressure conditions and forms additional esters in the presence of methanol [17].

Viscosity is one of the most important fuel properties of a biodiesel as it directly affects the engine operation. Biodiesels having high viscosity value may have poor fuel vaporisation and atomisation which also negatively affects the combustion and exhaust emissions [18]. Therefore, The British \& European standards for biodiesel, BS EN 14214 sets the upper limit of viscosity as $5.00 \mathrm{~mm}^{2} / \mathrm{s}$ [19]. However, biodiesels derived from waste animal fats generally have high viscosities and cannot be directly used in diesel engines $[12,20,21]$. Many researchers reported higher viscosity values than $5.00 \mathrm{~mm}^{2} / \mathrm{s}$ for the chicken fat biodiesels [15,21-26]. Different solutions have been proposed in the literature to solve this problem such as blending with fossil diesel, preheating of fuel and using fuel additives. However, all of the mentioned solutions had their own problems. Firstly, diesel blending of biodiesels is one of the most common applications in literature. Although this can reduce the viscosity within the range of BS EN 14214 standards, many studies state that fossil diesel depletion is inevitable, hence diesel blending may not be available in the future $[27,28]$. The second technique was the preheating of the fuel. Different engine modifications developed in the literature to reduce the viscosity before the injection. For example, Nanthagopal et al [29] benefited from the high-temperature exhaust system to increase the temperature of the ethanol-diesel blend by around $50^{\circ} \mathrm{C}$. In another study, Hossain and Davies [30] achieved to increase the temperatures of the neat jatropha and karanj oils up to $75^{\circ} \mathrm{C}$ and reduced the viscosities from $58 \mathrm{cSt}$ to $9 \mathrm{cSt}$ and 
from $80 \mathrm{cSt}$ to $11 \mathrm{cSt}$ by the help of hot jacket water, respectively. Although the heat from the exhaust system or jacket water can be used efficiently, these techniques require major engine modifications which mean extra space, increased weight and additional cost. Lastly, alcohols were one of the most frequently used fuel additives to reduce the viscosity of biodiesels [31-34]. For example, Yasin et al [31] added 5\% methanol into diesel-palm oil biodiesel blend $(75 \% / 20 \%)$. They reported $1.38 \mathrm{~mm}^{2} / \mathrm{s}$ reduction on the viscosity of the blend by the addition of methanol. However although, alcohol addition successfully reduced the viscosity, it negatively affected the engine performance and exhaust emissions. They observed an $8.3 \%$ reduction in engine power at medium engine speed and around $7 \%$ increase in $\mathrm{NO}$ emission at medium brake mean effective pressure after the alcohol addition [31].

Rather than mentioned solutions, chicken fat biodiesel can be blended with other biodiesels to optimise fuel properties, especially the viscosity. This technique may help to utilise chicken fat biodiesel in a more efficient manner such as avoiding fossil diesel blending, preventing any side effects of fuel additives and meeting the EN14214 standards.

Cottonseed oil biodiesel is a suitable agent to be blended with the chicken fat biodiesel due to its relatively lower viscosity. Alhassan et al [35] reported the viscosity of the cottonseed biodiesel as 4.38 $\mathrm{mm}^{2} / \mathrm{s}$ at $40^{\circ} \mathrm{C}$. Similarly, Venkatesan et al [36], Alptekin and Canakci [37] and Ramirez-Verduzco et al [38] addressed promising viscosity values for the cottonseed biodiesel as 3.75, 4.06 and 4.12 $\mathrm{mm}^{2} / \mathrm{s}$, respectively. As these values were lower than the upper limit of the BS EN 14214 standards, blends of the cottonseed biodiesel with the chicken fat biodiesel may comply with the standards. Besides, some researchers also observed lower $\mathrm{NO}_{\mathrm{x}}$ emission than diesel with the cottonseed biodiesel. Aydin and Bayindir [39] tested $100 \%$ cottonseed biodiesel in a single cylinder direct injection air cooled diesel engine. According to the study, cottonseed biodiesel had around $18 \%$ lower $\mathrm{NO}_{\mathrm{x}}$ emission than diesel at medium engine speeds. Similarly, Karabektas et al [40] observed a preheated cottonseed biodiesel in a single cylinder direct injection diesel engine and reported that $90{ }^{\circ} \mathrm{C}$ preheated cottonseed biodiesel had $5 \%$ lower $\mathrm{NO}_{\mathrm{x}}$ than diesel at $1800 \mathrm{rpm}$. In another study, Yucesu and Ilkilic [41] also tested $100 \%$ cottonseed biodiesel in a single cylinder air cooled diesel engine and reported $16 \%$ reduction in $\mathrm{NO}_{\mathrm{x}}$ emission compared to diesel at $2200 \mathrm{rpm}$.

Modern engines equipped with selective catalytic reduction (SCR) after treatment system may reduce the NOx emissions of biodiesel very effectively. However, their fuel supply systems like common rail direct injection may cause clogging problems when operated on high viscosity fuels. On the other hand, indirect injection type diesel engines are still widely used for different applications such as power generation and agricultural purposes [42]. Nonetheless, these engines do not necessarily have any modern after treatment systems, thus this study would contribute to reducing the emissions of indirect diesel engines and any engine not equipped with the SCR.

The main aim of this study is to reduce the viscosity of chicken fat biodiesel under the upper limit of the BS EN14214 standards by blending with cottonseed biodiesel. By this technique, some blends can comply with the BS EN 14214 standards and fuel properties can be optimised. In addition, chicken fat biodiesel can be utilised without any need of fossil diesel blending, engine modification, and any additive requirement. Objectives of the study were (i) to produce biodiesels via transesterification technique and blending of chickencottonseed biodiesels at various ratios. (ii) To characterise the fuel properties of the test fuels. (iii) To determine blend ratios comply with the BS EN 14214 standards. (iv) To test engine performance, combustion characteristics and exhaust gas emissions of novel blends and compare them to both $\mathrm{CO} 100$ and $\mathrm{CH} 100$ and diesel.

\section{Materials and Methods}

\section{Biodiesel Production}

Initially, waste chicken skin was collected from a local butcher shop. Then they were cut into smaller pieces and placed in an oven operating at $160^{\circ} \mathrm{C}$. After 40 minutes, rendered fat was collected. The chicken rendered fat was in the liquid phase even at the room temperature Figure 1.

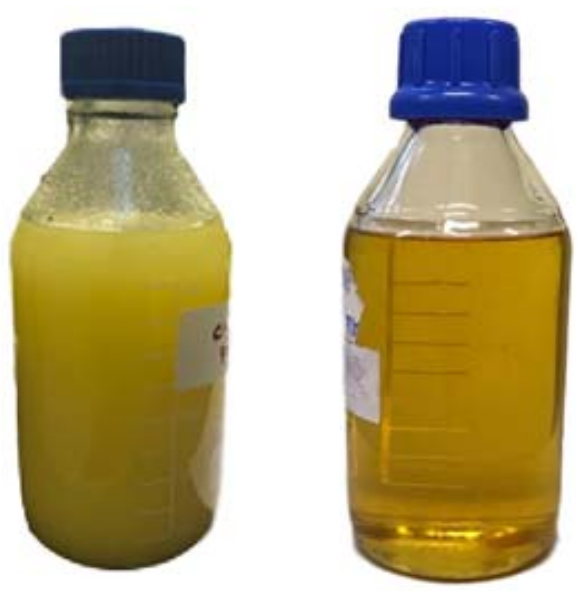

Fig ure 1. Chicken skin rendering fat (on the left) and cottonseed oil (on the right).

Both cottonseed oil and chicken rendering fat were converted into biodiesel via transesterification process. The laboratory scale equipment was used throughout the biodiesel production. $\mathrm{KOH}$ was used as a catalyst and mixed with the methanol in a baker under stirring condition. The amount of $\mathrm{KOH}$ was determined by the previously conducted titration method. The $1 \mathrm{ml}$ feedstock was mixed with the $10 \mathrm{ml}$ isopropanol and phenolphthalein indicator than titrated against $0.1 \mathrm{~N} \mathrm{KOH}$ solution. The amount of $\mathrm{KOH}$ solution consumed was used to determine the $\mathrm{KOH}$ needed for transesterification. The amount of methanol was equal to $20 \%$ of the feedstock to be transesterified. After $\mathrm{KOH}$ was completely dissolved in the methanol, the solution was added into feedstock which was at $60^{\circ} \mathrm{C}$. Then mechanical stirring applied on the mixture for about 30 minutes. Lastly, the mixture was poured into a separating funnel and allowed to have phase separation for 24 hours. The glycerol was settled down and biodiesel was accumulated at the top. The biodiesel production yield was calculated by dividing the amount of biodiesel produced by used feedstock before the transesterification [43]. For large scale production, the conventional commercial techniques can be used as described in literature [12]. Then the produced biodiesels can be blended easily without any necessity of aggressive stirring or surfactants.

Biomixtures were prepared by blending cottonseed biodiesel (CO100) and rendered chicken fat biodiesel (CH100) at 80/20, 60/40, $50 / 50,30 / 70$ and 10/90 volume ratios and named as $\mathrm{CO} 80 \mathrm{CH} 20$, $\mathrm{CO} 60 \mathrm{CH} 40, \mathrm{CO} 50 \mathrm{CH} 50, \mathrm{CO} 30 \mathrm{CH} 70$ and $\mathrm{CO} 10 \mathrm{CH} 90$ as shown in Table 1 . The commercially available Esso diesel (in the UK) was used as a reference fuel which involves $5 \%$ biodiesel in its content. Figure 2 presents the test fuels. There was no phase separation or miscibility problem in the biomixtures. 
Table 1. Biodiesel percentages of the biomixtures.

\begin{tabular}{|l|c|c|c|c|}
\hline \multicolumn{1}{|c|}{ Fuel } & \multicolumn{2}{|c|}{ Volume percentage of } & Fuel & Engine \\
\hline Name & $\begin{array}{c}\text { Cottonseed } \\
\text { biodiesel }\end{array}$ & $\begin{array}{c}\text { Chicken } \\
\text { biodiesel }\end{array}$ & Characterisation & Testing \\
\hline $\mathrm{CO} 100$ & $100 \%$ & $0 \%$ & Yes & Yes \\
\hline $\mathrm{CO} 80 \mathrm{CH} 20$ & $80 \%$ & $20 \%$ & Yes & NO \\
\hline $\mathrm{CO} 60 \mathrm{CH} 40$ & $60 \%$ & $40 \%$ & Yes & Yes \\
\hline $\mathrm{CO} 50 \mathrm{CH} 50$ & $50 \%$ & $50 \%$ & Yes & Yes \\
\hline $\mathrm{CO} 30 \mathrm{CH} 70$ & $30 \%$ & $70 \%$ & Yes & Yes \\
\hline $\mathrm{CO} 10 \mathrm{CH} 90$ & $10 \%$ & $90 \%$ & Yes & NO \\
\hline $\mathrm{CH} 100$ & $0 \%$ & $100 \%$ & Yes & Yes \\
\hline
\end{tabular}

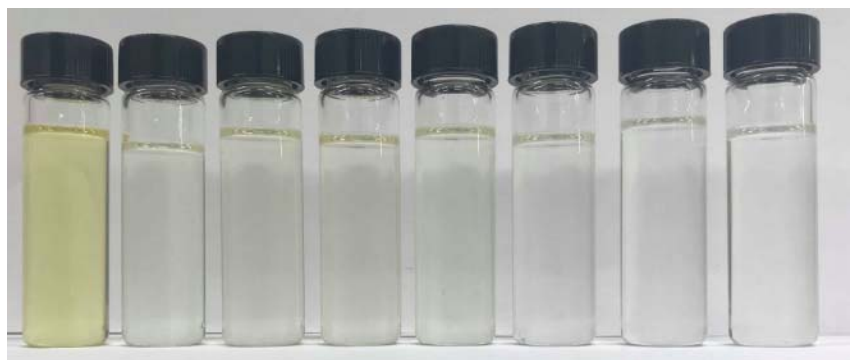

Figure 2. Appearance of the test fuels which are from left to right; Diesel, CO100, CO80CH20, CO60CH40, CO50CH50, CO30CH70, $\mathrm{CO} 10 \mathrm{CH} 90$ and $\mathrm{CH} 100$.

\section{Test Rig and Equipment}

The two neat biodiesels, diesel and three biomixtures which were $\mathrm{CO} 60 \mathrm{CH} 40, \mathrm{CO} 50 \mathrm{CH} 50$ and $\mathrm{CO} 30 \mathrm{CH} 70$ were tested in the engine to investigate the effect of cottonseed-chicken biodiesel blends on performance, combustion and emissions. Engine operating conditions like the height of the fuel tank, lubricant oil, exhaust piping, air aspiration system, brake mean effective pressure, compression ratio etc. were the same for all test fuels. It is well known that stationary engines are mainly operated at a constant engine speed especially for the agricultural purposes and power generation. Therefore, the engine speed was kept constant at the rated speed $(1500 \mathrm{rpm})$ throughout the experiment, whereas engine load was changing. Six different data sets were collected at $20 \%(1.9 \mathrm{~kW}), 40 \%(3.8 \mathrm{~kW}), 60 \%(5.7 \mathrm{~kW})$, $70 \%(6.65 \mathrm{~kW}), 80 \%(7.6 \mathrm{~kW})$ and $100 \%(9.75 \mathrm{~kW})$ engine loads to check the behaviors of the fuels at different engine loadings. An indirect injection type three-cylinder naturally aspired Lister Petter engine without EGR application was used to conduct this study. The specifications of the engine were listed in Table 2. This engine was mainly selected due to the recent trend on indirect injection engines for the advanced combustion research. Premixed Charge

Compression Ignition (PCCI), Reactivity Controlled Compression Ignition (RCCI) and Homogeneous Charge Compression Ignition (HCCI) were the recent examples [44-46]. In addition, some heavy duty diesel engines also use indirect injection system [47]. Although the engine does not meet emission standards, the results of the biofuels can give good indications to the researchers as they were compared to the diesel results at the same engine.

A Froude Hofmann AG80HS brand eddy current dynamometer was used for engine loading. A graduated cylinder was installed to fuel line to measure the fuel consumption. To measure the combustion characteristics Kistler products were used. A $6125 \mathrm{C} 11$ pressure sensor along with a 5064B11 charge amplifier was installed for the in-cylinder pressure measurement on the first cylinder. Fuel injection pressure was observed with the 4065A500A pressure sensor and the $4618 \mathrm{~A} 0$ amplifier. Crank angle was measured via 2614A optical sensor. All data were processed and analysed through the 2893AK8 KiBox data acquisition hardware equipped with the Cockpit software. Page 3 of 13
LabVIEW data acquisition system integrated with K-type thermoscouple used to monitor exhaust gas temperature. Figure 3 explains the test rig setup. The exhaust gases were analysed through Bosch BEA 850 gas analyser. The exhaust gases were measured directly from the exhaust pipe without any dilution.

Table 2. Engine specifications.

\begin{tabular}{|l|l|}
\hline Number of cylinders & 3 \\
\hline Engine manufacturer & Lister Petter (UK) \\
\hline Engine model & LPWS Bio3 water cooled \\
\hline Exhaust gas recovery (EGR) & $0 \%$ \\
\hline Rated speed & $1500 \mathrm{rpm}$ \\
\hline $\begin{array}{l}\text { Continuous power at rated } \\
\text { speed }\end{array}$ & $9.9 \mathrm{~kW}$ \\
\hline Fuel pump injection timing & $20^{\circ} \mathrm{bTDC}$ \\
\hline Fuel injection type & $\begin{array}{l}\text { Indirect injection. Self-vent fuel } \\
\text { system with individual fuel injection } \\
\text { pumps }\end{array}$ \\
\hline Cylinder volume & 1.395 litre \\
\hline Aspiration & Naturally aspired \\
\hline
\end{tabular}

Initially, the engine was started and run on diesel for 30 minutes to avoid the cold start effect. Then tests were started with fossil diesel. Before switching to new fuel, the fuel supply system was flushed with the new fuel prior to measurements. Moreover, the engine was run at least 4 minutes after each load change to collect data in the steady-state condition. 51 cycles of combustion data were collected via KiBox, and then the average of readings calculated for minimising the cycle errors. Engine geometry, pressure versus volume cycle, and the first law of thermodynamics were used in the evaluation of combustion characteristics. Adiabatic expansion and compression were assumed during the combustion process and heat losses to walls did not take into account. KiBox cockpit software was used to analyse the start of injection (SOI), start of combustion (SOC), ignition delay (ID), end of combustion (EOC), combustion duration (CD), in-cylinder pressure and total heat release. The crank angle when the fuel injection pressure was built up was assumed as a SOI point. Moreover, $5 \%$ and $90 \%$ of heat release were assumed as the start and end of combustion. Ignition delay corresponds to crank angle difference between the SOC and SOI. Similarly, combustion duration is the crank angle difference between the EOC and SOC.

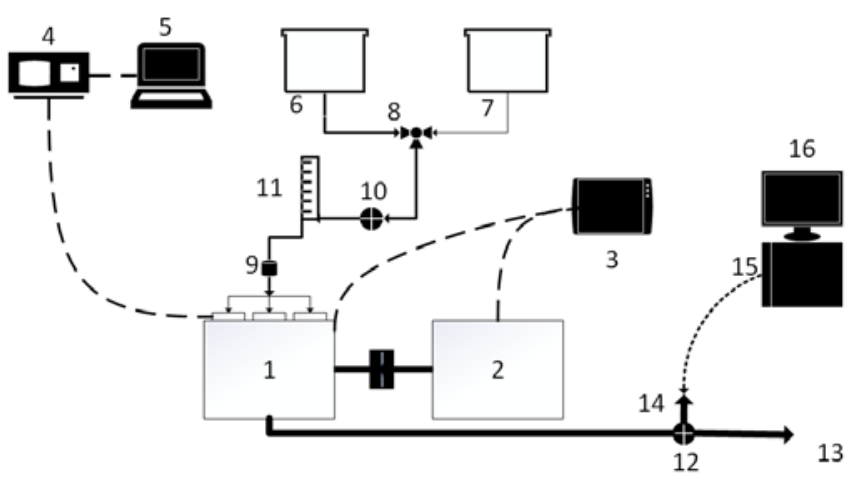

Figure 3. Schematic diagram of the experimental setup. 1 engine, 2 Dynamometer, 3 Dynamometer controller, 4 KiBox combustion analyser, 5 laptop to record combustion data, 6 diesel tank, 7 biofuel tank, 8 three-way valve, 9fuel filter, 10 valve, 11 fuel meter, 12 valve, 13 Exhaust pipe exit, 14 Exhaust pipe opening to measure emissions, 15 emission analyser, 16 computer to record emission data 


\section{Results and Discussions}

\section{Fuel Characterisation}

Approximately $2.2 \mathrm{~kg}$ of fat rendered out of the $5 \mathrm{~kg}$ chicken skin, thus the yield of rendering process was calculated as $43.5 \%$. However, yields of biodiesel productions for both cottonseed oil and chicken fat were around $92 \%$. All biofuels were tested in a gas chromatograph and mass spectrum (GC-ms) analyser to find fatty acid methyl ester (FAME) compositions. The Trace 1300 type Thermo Scientific brand gas chromatography equipped with the ISQLT brand mass spectrum analyser was used at Aston University chemical engineering laboratories. The samples were prepared by dissolving $0.1 \mathrm{~g}$ of biofuel in $100 \mathrm{ml}$ of methanol. The $0.1 \mu \mathrm{L}$ volume of samples was tested through the Perkin Elmer brand column which was $30 \mathrm{~m}$ in length, $0.22 \mathrm{~mm}$ in diameter and $0.25 \mu \mathrm{m}$ of film thickness. The injector was set to $280{ }^{\circ} \mathrm{C}$ and a split mode (with $1: 10$ ratio) was used during the injection of the samples. The oven was at $100{ }^{\circ} \mathrm{C}$ at the first 1 minute and the temperature was increased by the increments of $10^{\circ} \mathrm{C}$ per minute up to $275^{\circ} \mathrm{C}$. Electron impact ionisation was used at the mass spectrometer to scan within the range of $50-600 \mathrm{~m} / \mathrm{z}$. The temperatures of the ion source and mass transfer line were $200{ }^{\circ} \mathrm{C}$ and $250{ }^{\circ} \mathrm{C}$ respectively. Figure 4 illustrates the sample GC-ms results which belong to CO50CH50 biomixture. It should be noted that free glycerol, mono-, di-, tri- glycerides, oxidation stability and metals content were not measured in this study. However, according to Figure 4, there was not any significant peak which might belong to free glycerol, mono-, di-, or triglycerides. The EN 14214 standard limits the mole percentages of mono-glyceride maximum to 0.8 , di- and tri-glycerides maximum to 0.2 and free glycerol maximum to 0.02 .

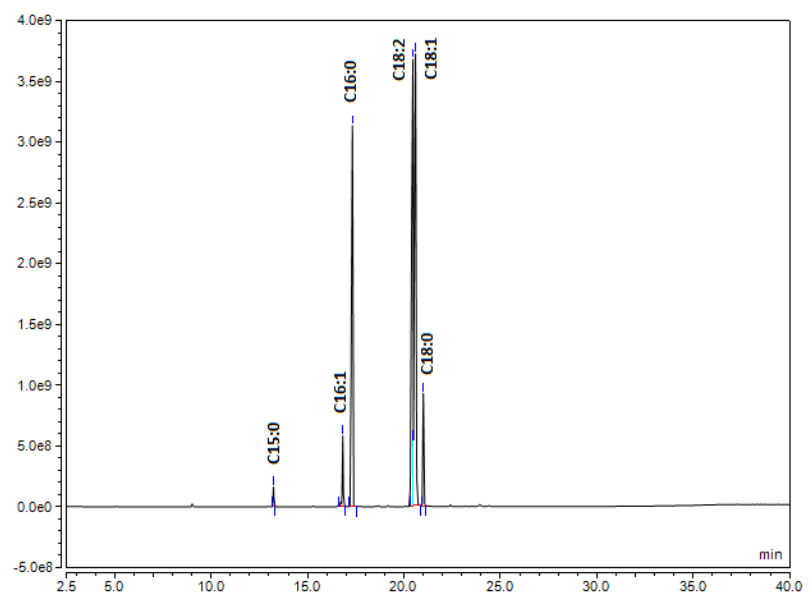

Figure 4. FAME distributions of the CO100, $\mathrm{CH} 100$ and biomixtures according to saturated, monounsaturated and polyunsaturated FAME percentages.

Table 3 shows the FAME mass percentage breakdowns of the biofuels. Results showed that both base fuels i.e. cottonseed biodiesel and chicken biodiesel have a similar fraction of saturated FAMEs as $26.7 \%$ and $28.8 \%$ respectively. Ultimately, their total unsaturation percentages were also close to each other as $73.3 \%$ and $71.2 \%$ respectively. However, the type of unsaturated FAME has a vital influence on the iodine value of biodiesel [48]. The results revealed that cottonseed biodiesel was mainly consisted of polyunsaturated FAME (C18:2) as 51.7\%, whereas chicken biodiesel had the monounsaturated FAMEs (C16:1 and C18:1) as 48.8\% in total.

The FAME breakdowns of each biofuel were used to determine some fuel properties such as cetane numbers, carbon, hydrogen and oxygen contents, lower heating values, iodine numbers and degrees of unsaturation. On the other hand, viscosity, density, flash point, higher heating value and acid value were measured at the Aston University laboratories according to the methods declared by the European standards i.e. EN ISO 3675 for density, EN ISO 3104 for the kinematic viscosity, and EN ISO 3679 for flash point.

Table 3. Fatty Acid Methyl Ester compositions of the biofuels.

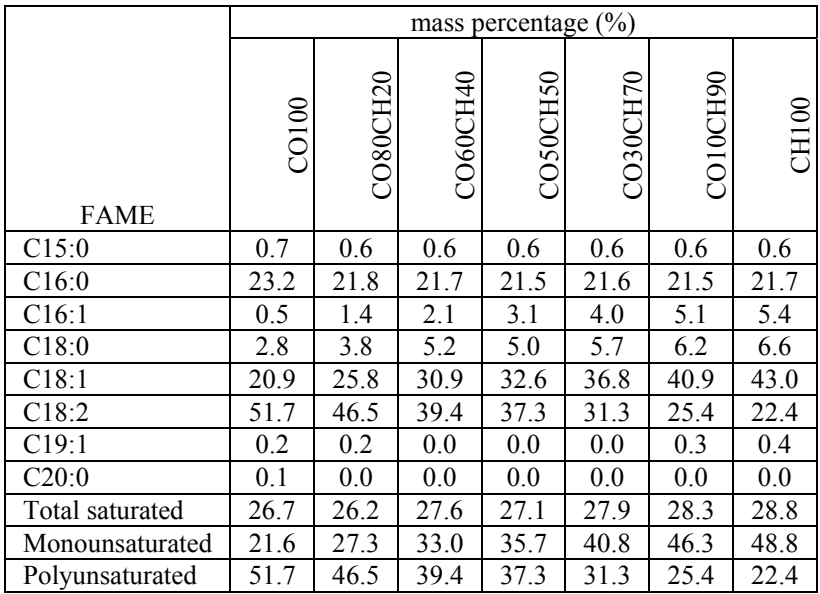

The physicochemical properties of $\mathrm{CO} 100, \mathrm{CH} 100$, biomixtures, and diesel were presented in Table 4 along with The British \& European

Table 4. Fuel properties of the test fuels with the corresponding EN14214 biodiesel [19] and EN 590 diesel [49] standards.

\begin{tabular}{|c|c|c|c|c|c|c|c|c|c|c|c|}
\hline Fuel & Units & & & & Biofuels & & & & & EN 14214 & EN 590 \\
\hline Properties & & 응 & 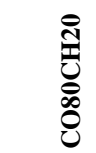 & 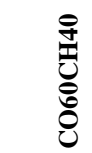 & 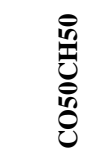 & 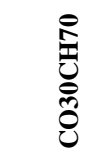 & 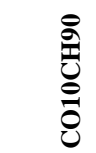 & $\underset{8}{\stackrel{8}{\Xi}}$ & Diesel & $\begin{array}{l}\text { Biodiesel } \\
\text { Standards }\end{array}$ & $\begin{array}{c}\text { Diesel } \\
\text { Standards }\end{array}$ \\
\hline Viscosity at $40^{\circ} \mathrm{C}$ & $\mathrm{mm}^{2} / \mathrm{s}$ & 4.33 & 4.48 & 4.66 & 4.92 & 5.10 & 5.16 & 5.36 & 2.78 & $3.5-5.0$ & $2.0-4.5$ \\
\hline Density & $\mathrm{g} / \mathrm{cm}^{3}$ & 0.884 & 0.882 & 0.882 & 0.881 & 0.880 & 0.880 & 0.878 & 0.828 & $0.86-0.90$ & $\begin{array}{c}0.820- \\
0.845\end{array}$ \\
\hline Flash Point & ${ }^{\circ} \mathrm{C}$ & 176 & 176 & 173 & 171 & 168 & 165 & 165 & 61.5 & $>101$ & $>55$ \\
\hline Cetane number & - & 54 & 55 & 57 & 57 & 59 & 60 & 60 & 45.7 & $>51$ & $>51$ \\
\hline
\end{tabular}

Page 4 of 13 


\begin{tabular}{|c|c|c|c|c|c|c|c|c|c|c|c|}
\hline Carbon & $\%$ & 76.13 & 76.23 & 76.34 & 76.32 & 76.29 & 76.02 & 75.95 & $\begin{array}{l}86.6 \\
{[50]}\end{array}$ & $\mathrm{n} / \mathrm{a}$ & $\mathrm{n} / \mathrm{a}$ \\
\hline Hydrogen & $\%$ & 11.93 & 11.97 & 12.05 & 12.06 & 12.10 & 12.10 & 12.11 & $\begin{array}{l}13.4 \\
{[50]}\end{array}$ & $\mathrm{n} / \mathrm{a}$ & $\mathrm{n} / \mathrm{a}$ \\
\hline Oxygen & $\%$ & 10.97 & 10.98 & 11.00 & 11.01 & 11.02 & 10.99 & 10.99 & $\begin{array}{l}0.07 \\
{[50]}\end{array}$ & $\mathrm{n} / \mathrm{a}$ & $\mathrm{n} / \mathrm{a}$ \\
\hline HHV & $\mathrm{MJ} / \mathrm{kg}$ & 39.4 & 39.4 & 39.6 & 39.4 & 39.1 & 39.6 & 39.3 & 45.2 & $\mathrm{n} / \mathrm{a}$ & $\mathrm{n} / \mathrm{a}$ \\
\hline LHV & $\mathrm{MJ} / \mathrm{kg}$ & 37 & 37 & 37 & 37 & 37 & 37 & 37 & 42 & $\mathrm{n} / \mathrm{a}$ & $\mathrm{n} / \mathrm{a}$ \\
\hline Iodine number & $\mathrm{g} / 100 \mathrm{~g}$ & 111 & 108 & 101 & 100 & 94 & 88 & 85 & $\mathrm{n} / \mathrm{a}$ & $<120$ & $\mathrm{n} / \mathrm{a}$ \\
\hline Acid value & $\begin{array}{c}\mathrm{mg} \\
\mathrm{KOH} / \mathrm{g}\end{array}$ & 0.228 & 0.200 & 0.200 & 0.171 & 0.172 & 0.172 & 0.172 & 0.091 & $<0.5$ & $\mathrm{n} / \mathrm{a}$ \\
\hline $\begin{array}{c}\text { Degree of } \\
\text { Unsaturation }\end{array}$ & Weight \% & 125 & 120 & 112 & 110 & 103 & 97 & 94 & $\mathrm{n} / \mathrm{a}$ & $\mathrm{n} / \mathrm{a}$ & $\mathrm{n} / \mathrm{a}$ \\
\hline
\end{tabular}

biodiesel standards, BS EN 14214 [19] \& EN 590 diesel standards [49]. Viscosity, cetane number and iodine value were found as mostly effected fuel properties due to the blending of cottonseed-chicken biodiesels. Figure 5 illustrates the variation of viscosity and cetane number with respect to cottonseed-chicken biodiesel ratio. Both properties were increased with the increased fraction of the chicken biodiesel in the blends. This can be attributed to the relatively low amount of polyunsaturated FAME content of the $\mathrm{CH} 100$ as $22.4 \%$.

Viscosity is a crucial fuel property as it directly affects the atomisation quality of the fuel [37]. The viscosity of CH100 biodiesel was measured as $5.36 \mathrm{~mm}^{2} / \mathrm{s}$ which was not complied with BS EN 14214 standards. The main reason of high viscosity was relatively low degree of unsaturation and iodine value of the CH100. It is well known that FAMEs with low number of double bonds (low degree of unsaturation and iodine value) have higher viscosities [50].

However, blends containing at least $50 \%$ cottonseed biodiesel like $\mathrm{CO} 50 \mathrm{CH} 50, \mathrm{CO} 60 \mathrm{CH} 40, \mathrm{CO} 80 \mathrm{CH} 20$ and $\mathrm{CO} 100$ had viscosities less than $5.0 \mathrm{~mm}^{2} / \mathrm{s} \mathrm{limit}$ and met the standards. Similarly, density also influences the combustion and engine performance [43]. All biofuels met the BS EN 14214 standards in terms of density. The $\mathrm{CO} 100$ had the highest density of $0.884 \mathrm{~g} / \mathrm{cm}^{3}$. The density of the blends reduced with the increased percentage of chicken biodiesel. Flash point is an important parameter for safe storage and transport of the fuels. The flash points of all biofuels were changing between $176^{\circ} \mathrm{C}$ and $165^{\circ} \mathrm{C}$ which complied with the standards. Cetane number is a good measure of the ignition quality of any fuel [51]. CN numbers of each biofuel were calculated from their FAME compositions as shown in equation 1 [52].

$$
C N_{\text {biodiesel }}=\sum\left(C N_{F A M E}\right)(\text { mass percentage of FAME })
$$

All biofuels had higher $\mathrm{CN}$ values than the 51 limit declared by the standards. Among the biofuels, $\mathrm{CO} 100$ had the minimum $\mathrm{CN}$ as 54 and $\mathrm{CN}$ of the biofuels was increasing in accordance with the increasing chicken biodiesel fraction. The $\mathrm{CO} 60 \mathrm{CH} 40$ and $\mathrm{CO} 50 \mathrm{CH} 50$ biomixtures had similar $\mathrm{CN}$ as 57 , and maximum $\mathrm{CN}$ value was observed with $\mathrm{CH} 100$ as 60 . The carbon, hydrogen and oxygen contents of the biofuels were found very close to each other and matched with the literature [53]. All biofuels had almost the same energy contents and lower heating values as $39.4 \mathrm{MJ} / \mathrm{kg}$ and 37 $\mathrm{MJ} / \mathrm{kg}$ which were slightly lower than diesel. Iodine number and

Page 5 of 13 degree of unsaturation both measures the saturation level of any animal fat or vegetable oil [54]. The iodine value of any FAME increases with an increasing number of double bonds in its molecular structure and the biofuels becomes more unsaturated. All biofuels met the iodine value standard which was declared as maximum $120 \mathrm{~g}$ iodine $/ 100 \mathrm{~g}$ in BS EN14214. Iodine values of the blends decreased with respect to the increased percentage of the chicken biodiesel. The acid value is a good indication of biodiesels resistance to ageing [55]. The acid values of all biofuels were below the maximum limit of 0.5 $\mathrm{mg} \mathrm{KOH} / \mathrm{g}$. This shows that biofuels can be safely used in an engine in terms of pump plugging and corrosion $[43,55]$. Consequently, Chicken biodiesel did not meet the BS EN 14214 standards in terms of viscosity. However, blending of cottonseed biodiesel with chicken biodiesel at $60 / 40$ and 50/50 volume ratios generated high-quality biomixtures complied with the standards. In other words, no other additives, engine modification or fossil diesel blending was required for the engine application.

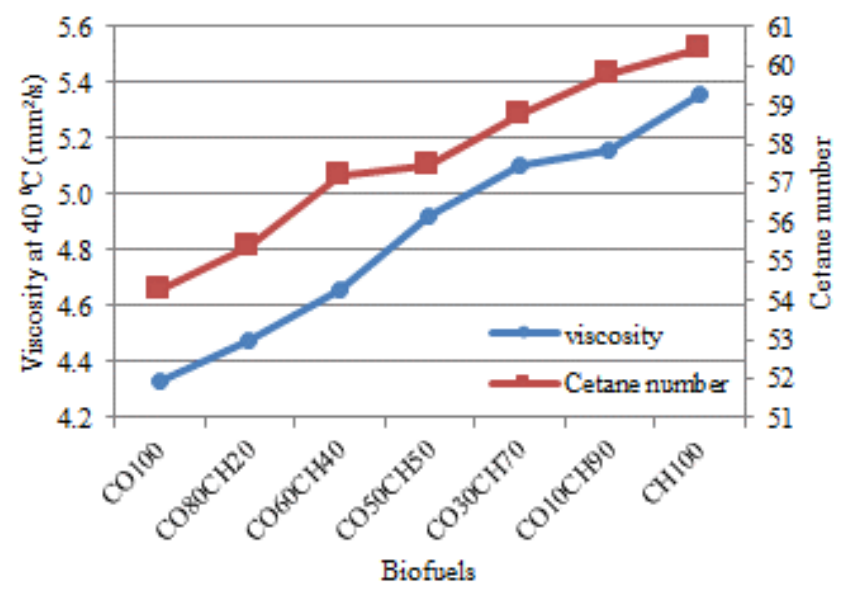

Figure 5. Variation of viscosity and cetane number with respect to cottonseed-chicken biodiesel ratio.

The fuel properties of the biomixtures i.e. CO50CH50 were in good agreement with the similar studies in the literature. For example, Benjumea et al [56] blended the palm and linseed biodiesels in 50/50 volume fraction. This biofuel blend had comparable density (as 0.885 $\mathrm{g} / \mathrm{cm}^{3}$ ), HHV (as $39.8 \mathrm{MJ} / \mathrm{kg}$ ) and iodine value (as $112.7 \mathrm{~g} / 100 \mathrm{~g}$ ) with the CO50CH50. Moreover, the mentioned biofuel blend had a $10 \%$ lower cetane number (as 51.3 ) than the $\mathrm{CO} 50 \mathrm{CH} 50$ biomixture investigated in this study. In another study, Sanjid et al [57] studied the Kapok biodiesel-Moringa biodiesel-diesel blend which had volume percentages of 10/10/80 respectively. This fuel had around $30 \%$ lower viscosity value (as $3.40 \mathrm{~mm}^{2} / \mathrm{s}$ ) than the $\mathrm{CO} 50 \mathrm{CH} 50$, because of the high percentage of diesel as $80 \%$. However, the cetane number of the mentioned fuel was approximately $16 \%$ lower than the CO50CH50. Overall, the biomixtures investigated in this study had 
comparable fuel properties with the similar type of biofuel blends in literature. Moreover, the fuels presented in this study were better in terms of the cetane numbers as the chicken biodiesel had relatively high $\mathrm{CN}$ as 60

\section{Engine Performance}

Figure 6 demonstrates the Brake Thermal Efficiency (BTE) of the test fuels with respect to different engine loads. Blends having relatively higher cottonseed biodiesel ratio had better performance at low and medium engine loads. CO100, CO60CH40, CO50CH50 had around $10 \%$ higher BTE than other biofuels and diesel at $40 \%$ load. This is due to the presence of oxygen in the content of biodiesel which enhances the combustion characteristics of the fuel. However, all biofuels had slightly reduced $1.6 \%$ BTE than diesel at the full load condition. This result is in agreement with the literature. Despite the presence of oxygen, diesel can provide higher BTE than biodiesel due to its higher Lower Heating Value (LHV) than biodiesel [43].

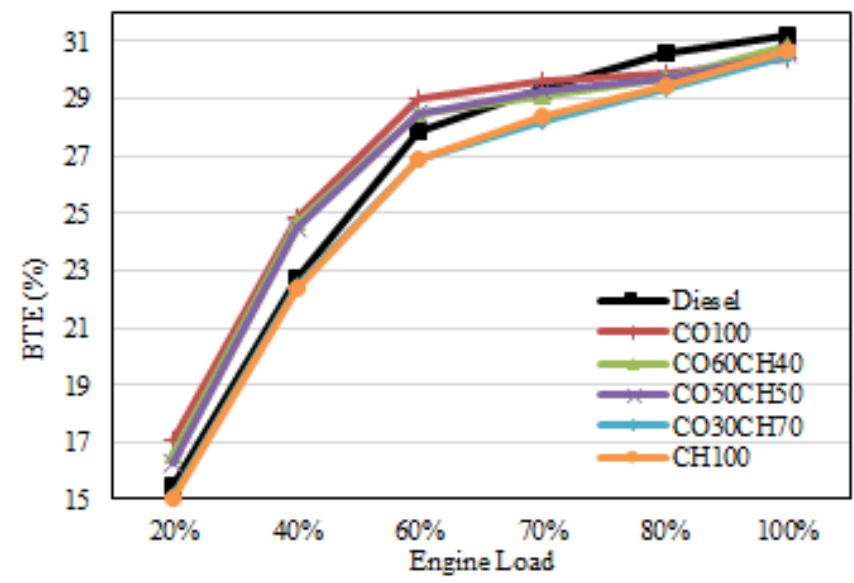

Figure 6. BTE of the test fuels.

Figure 7 shows the (a) Brake Specific Fuel Consumption (BSFC) and (b) Brake Specific Energy Consumption (BSEC) of the test fuels at different engine loads. BSFC of all biofuels found higher than the diesel at each engine load and was $15.4 \%$ higher than the diesel at full load condition. An increasing trend on BSFC was observed with the decreasing iodine number, especially at low and medium engine loads. To illustrate, $\mathrm{CH} 100$ and $\mathrm{CO} 30 \mathrm{CH} 70$ biofuels with relatively high iodine numbers had $5.6 \%$ and $14.4 \%$ higher BSFCs than the other biofuels and diesel at $60 \%$ engine load, respectively. However, all biofuels had the same BFSC at the high engine loads due to the same LHV. In order to eliminate the effect of LHV, BSEC can be used to compare the energy consumption of an engine when operated on different LHV fuels $[58,59]$. This allows comparing the test fuels in terms of the energy consumed to produce the same power output. Figure 7 (b) indicates that $\mathrm{CO} 100, \mathrm{CO} 60 \mathrm{CH} 40, \mathrm{CO} 50 \mathrm{CH} 50 \mathrm{had}$ around $11.8 \%$ lower BSEC than the $\mathrm{CO} 30 \mathrm{CH} 70, \mathrm{CH} 100$ and diesel at $40 \%$ engine load. Moreover, all test fuels including diesel had almost the same BSEC at the full engine load condition. To sum up, the engine consumed comparable energy on every test fuels. In other words, diesel did not have any superiority to biofuels at the full load condition.

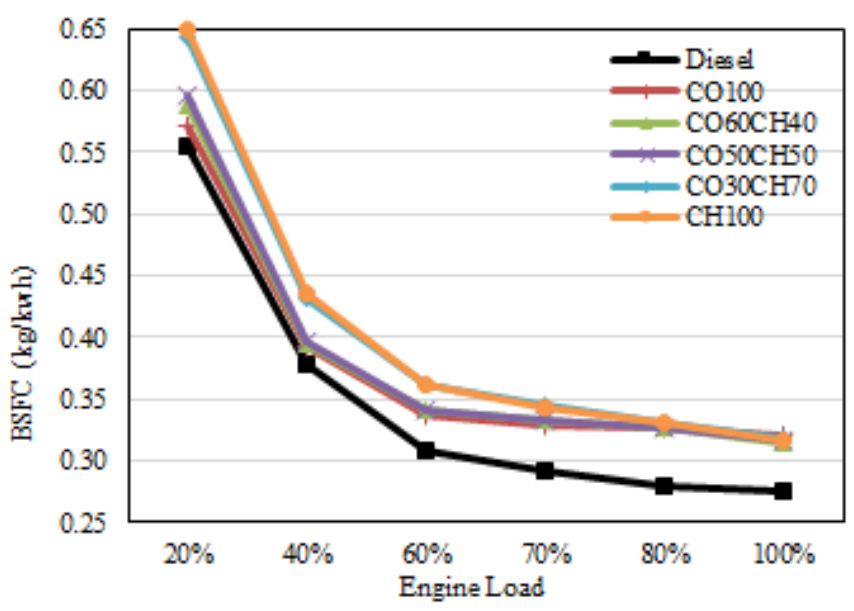

(a)

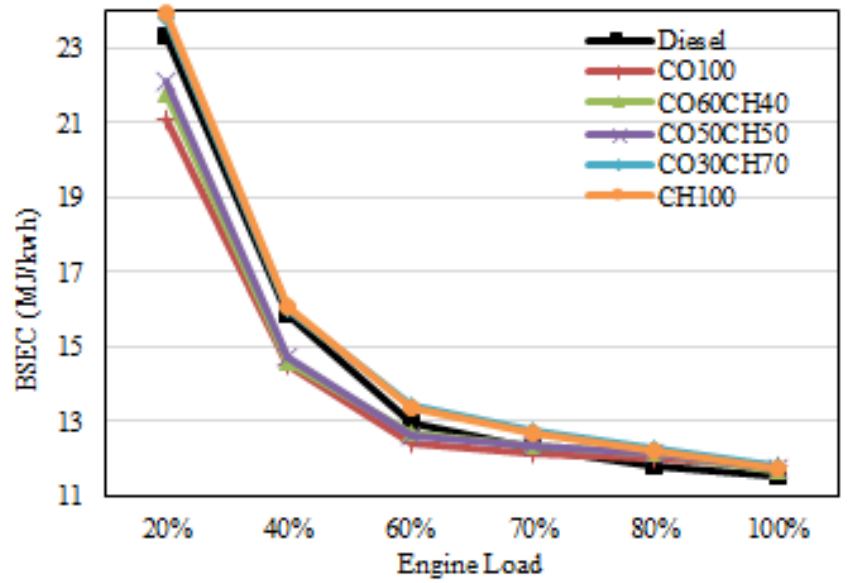

(b)

Figure 7. BSFC and BSEC of the test fuels.

\section{Injection and Combustion Characteristics}

Figure 8 represents the start, end times of the combustion as well as overall combustion duration for the all test fuels. No significant change on SOC was observed with respect to engine load, whilst EOC was linearly increasing according to increasing engine load for all fuels. This is due to increased amount of fuel at higher engine loads to overcome the higher resistance. Ultimately, the total combustion durations of all test fuels were also higher at the high engine loads. 


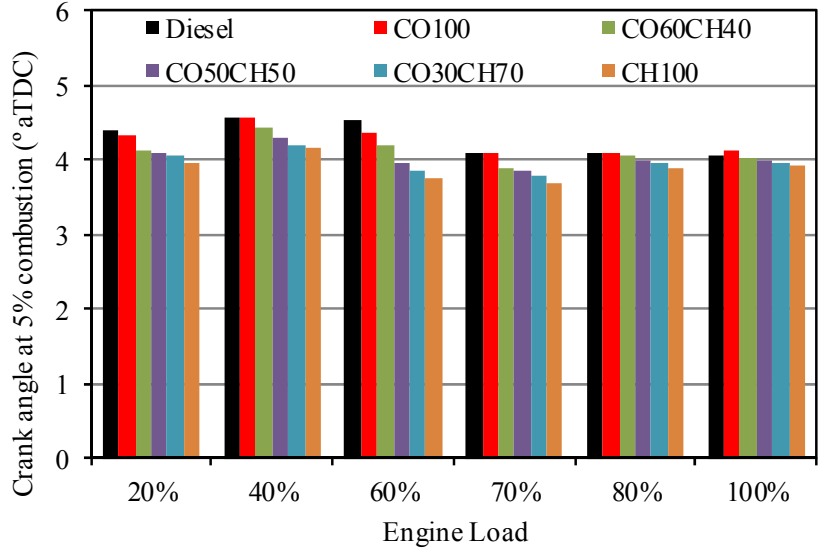

(a)

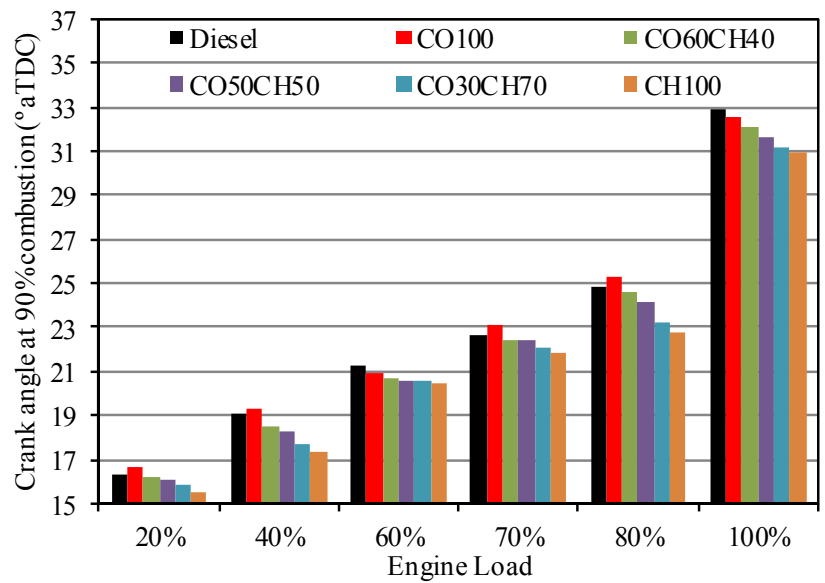

(b)

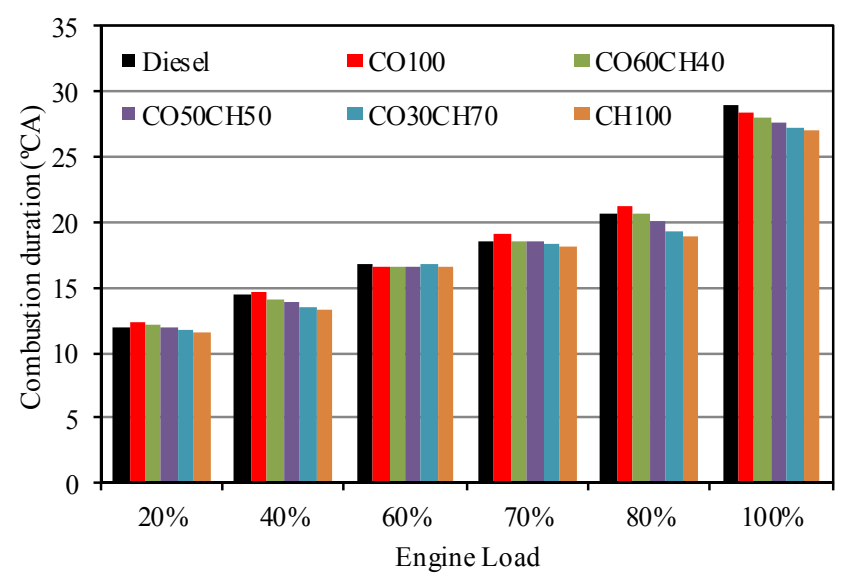

(c)

Figure 8. Combustion (a) start, (b) end times and (c) combustion duration in terms of crank angles.

Ignition delay and combustion durations were investigated in more detail in Figure 9. Chicken biodiesel had the shortest ID at all engine loads due to its high cetane number. Approximately $0.2^{\circ} \mathrm{CA}$ and $0.1^{\circ} \mathrm{CA}$ longer ID were measured for each 2 reduction on cetane number at medium and high engine loads respectively. In other words, the higher the cottonseed biodiesel ratio, the longer the ignition delay and combustion duration. This can be explained by the relatively higher iodine number, density and lower cetane number of cottonseed oil. Both $\mathrm{CO} 60 \mathrm{CH} 40$ and $\mathrm{CO} 50 \mathrm{CH} 50$ biomixtures had the average ID and $\mathrm{CD}$ values as $4.0^{\circ} \mathrm{CA}$ and $28^{\circ} \mathrm{CA}$ at the full engine load condition.

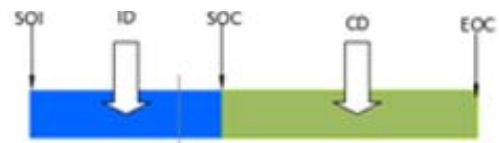

TDC

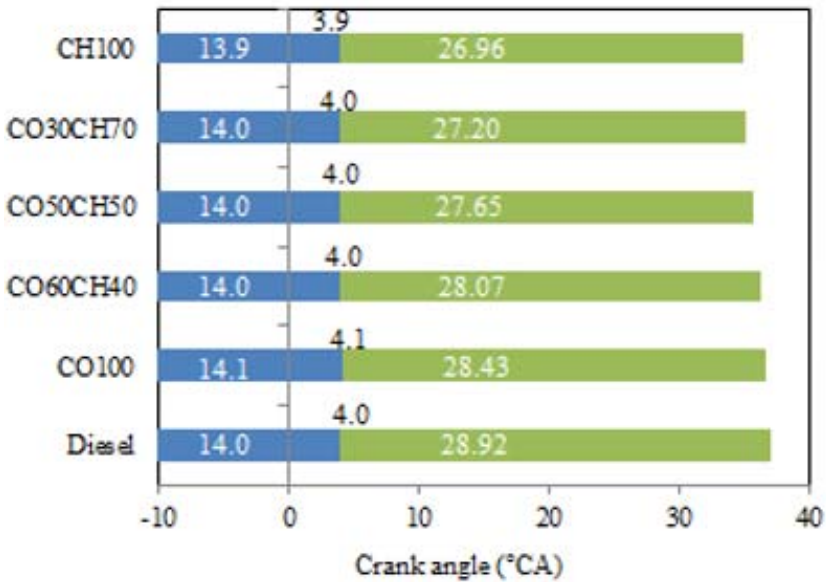

Figure 9. Ignition delay and combustion duration of the test fuels at the full engine load.

The effective heat energy of any fuel can be understood by the exhaust gas temperature (EGT) [60]. The higher the EGT, the lower the conversion of energy to useful work [43]. Moreover, $\mathrm{NO}_{\mathrm{x}}$ emission and BSFC are likely to increase with the higher EGT [60]. EGTs of the test fuels were measured and given in Figure 10. Like in the case of CD, EGT also rose with the increasing engine load because of the escalating amount of consumed fuel. In general, all biofuels had lower EGT than the diesel. The CO50CH50 biomixture had the lowest EGT at each engine load i.e. $7.8 \%, 6.9 \%$ and $2.4 \%$ lower than diesel, $\mathrm{CO} 100$ and $\mathrm{CH} 100$ at full engine load respectively. Diesel had the highest EGT and it was followed by the CO100 and $\mathrm{CO} 60 \mathrm{CH} 40$ at each engine load. Longer combustion durations may cause some of the fuel to be burned in the expansion stroke where the combustion chamber volume gets larger. This phenomena results in converting the fuel energy in to exhaust temperature rather than useful energy [61], which explained the reason of higher EGT of diesel, $\mathrm{CO} 100$ and $\mathrm{CO} 60 \mathrm{CH} 40$. To illustrate, diesel had $0.5^{\circ} \mathrm{CA}$ longer combustion duration than $\mathrm{CO} 50 \mathrm{CH} 50$ at $60 \%$ engine load which result in $10^{\circ} \mathrm{C}$ higher EGT. 


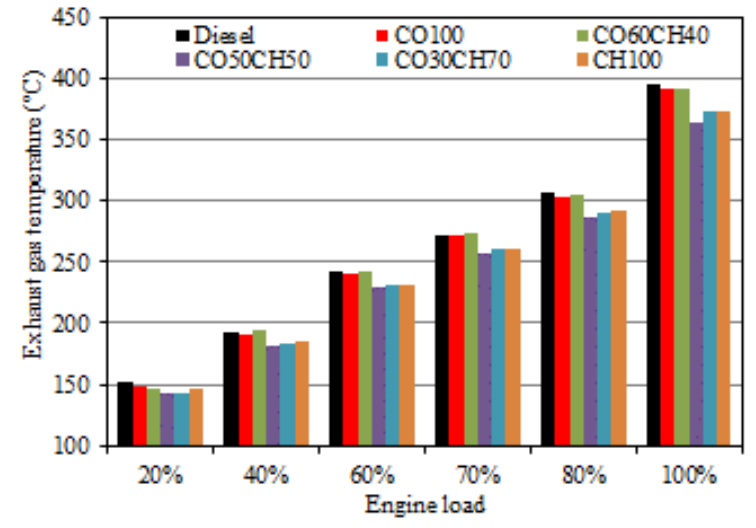

Figure 10. Exhaust gas temperature at different engine loads.

The in-cylinder pressures of the biofuels and diesel were demonstrated in Figure 11. The in-cylinder pressure trends of the biomixtures were smooth like diesel which prove there was no abnormalities or uneven burning of the novel biomixtures [62]. The $\mathrm{CO} 50 \mathrm{CH} 50$ had the highest peak in-cylinder pressure as $71.8 \mathrm{bar}$ at $10.7^{\circ} \mathrm{CA}$; which was approximately $4.2 \%$ and $4.5 \%$ higher than the diesel and other biofuels at full load. The optimised fuel properties (by blending) might be the reason why the pressure of CO50CH50 was the highest. In other words, although CO100 had the lowest viscosity value as $4.33 \mathrm{~mm}^{2} / \mathrm{s}$; it had lower $\mathrm{CN}$ (as 54) and higher degree of unsaturation (as 125) than $\mathrm{CH} 100$ (which has $\mathrm{CN}$ as 60 and a degree of unsaturation as 94). This shows that the high viscosity detriment of $\mathrm{CH} 100$ and the low $\mathrm{CN}$ disadvantage of $\mathrm{CO} 100$ were both eliminated when they were blended to form CO50CH50. Figure 12 presents the heat releases of the test fuels at different crank angles. Similar to in-cylinder pressure, $\mathrm{CO} 50 \mathrm{CH} 50$ had the highest heat release at the early phase of the combustion between $5^{\circ} \mathrm{CA}$ and $25^{\circ} \mathrm{CA}$ aTDC. To illustrate, figure 12 (b) presents that CO50CH50 released $249 \mathrm{~J}$ of heat at $12^{\circ} \mathrm{CA}$, whereas diesel released $238 \mathrm{~J}$ of heat at the same crank angle which was $4.4 \%$ lower than the CO50CH50. After the $35^{\circ} \mathrm{CA}, \mathrm{CO} 60 \mathrm{CH} 40$ had the highest heat release which was approximately $3.8 \%$ higher than the other fuels including the diesel at $69^{\circ} \mathrm{CA}$. The main reasons for the changes in heat release might be the varying iodine values (and the degrees of unsaturation) and viscosities of the test fuels. It was observed that biofuels having relatively lower iodine values tends to burn quicker because of the less number of double bonds in their chemical structures [48]. Nevertheless, their relatively high viscosities lead to poor atomisation which reduces the burning quality of the fuel [20]. Therefore, $\mathrm{CO} 50 \mathrm{CH} 50$ and $\mathrm{CO} 60 \mathrm{CH} 40$ had the highest heat releases due to optimised iodine values and viscosities.

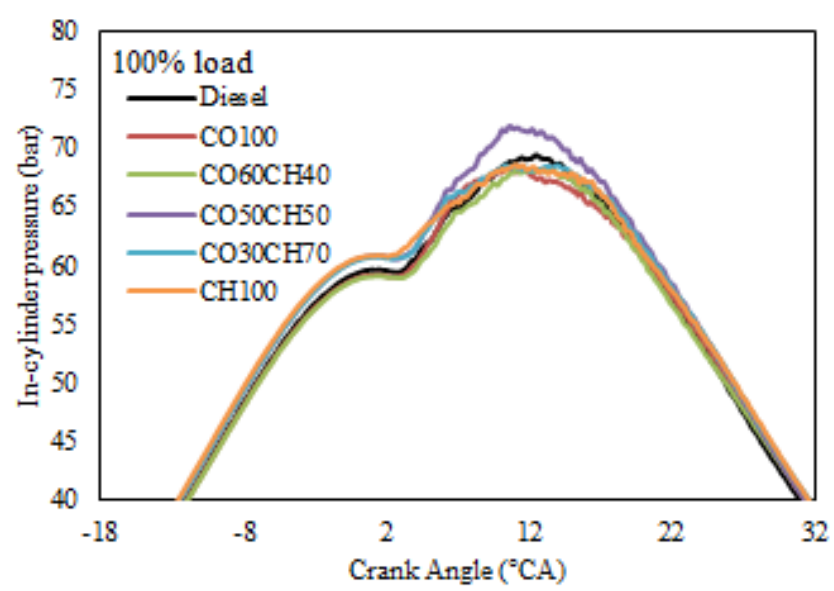

Figure 11. In-cylinder pressure versus crank angle.

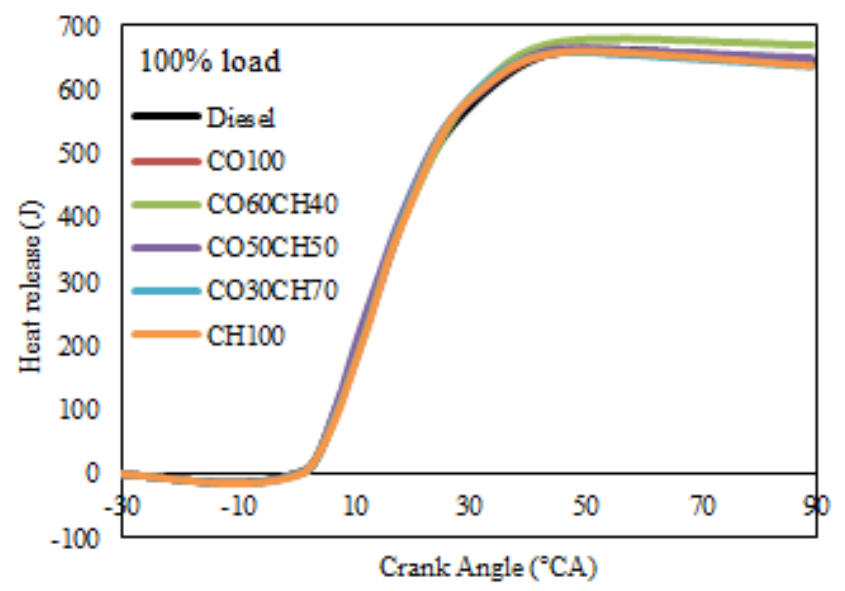

(a)

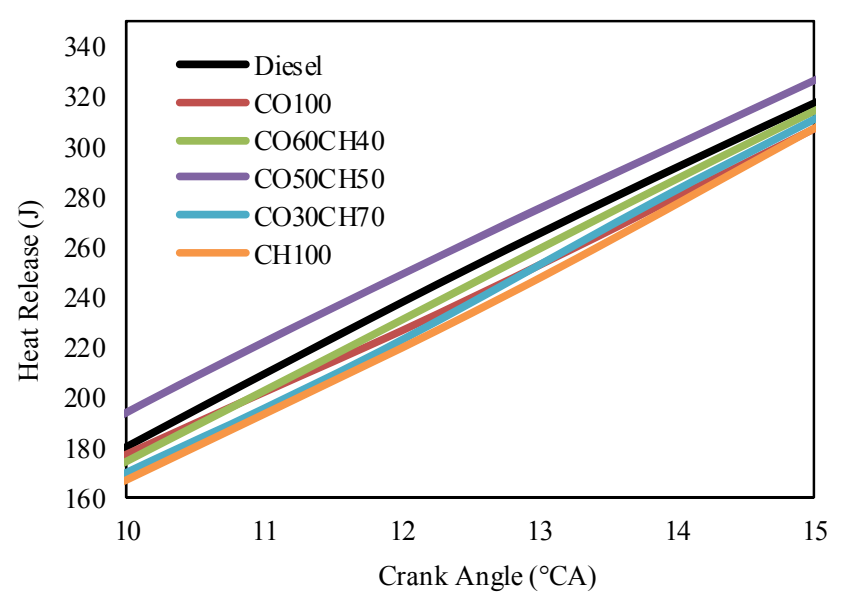

(b)

Figure 12. Heat release of test fuels at versus crank angles (a) whole combustion period, (b) early combustion phase between the crank angles of 10 and 15 .

\section{Exhaust Gas Emissions}

$\mathrm{CO}_{2}, \mathrm{CO}$ and $\mathrm{NO}$ emissions of biomixtures were analysed as instantaneous pollutant concentrations and compared to CO100, 
CH100 and diesel. The readings were collected at the steady-state condition which was monitored by the stability of the instantaneous readings. As shown in Figure 13, the $\mathrm{CO}_{2}$ emission rose with increasing load. This was due to the increased fuel consumption at high engine speeds which increased the carbon atoms in combustion reaction. Oxygen content and burning efficiency are the other important factors in $\mathrm{CO}_{2}$ emission of any fuel [63]. Carbon and oxygen contents of the test fuels were reported very close to each other in Table 4. Ultimately, any difference on $\mathrm{CO}_{2}$ emissions can be attributed to burning efficiency of the test fuels. The results indicated that among the two neat biodiesels, $\mathrm{CO} 100$ had 5.4\% more $\mathrm{CO}_{2}$ emission than $\mathrm{CH} 100$. Compared to diesel, $\mathrm{CO} 100$ had $2.8 \%$ higher $\mathrm{CO}_{2}$ emission, whereas $\mathrm{CH} 100$ had $2.8 \%$ lower $\mathrm{CO}_{2}$ emission. Although however, chicken fat biodiesel has viscosity limitations according to BS EN 14214 standards and cannot be directly used in an engine, this advantage of the chicken biodiesel was also observed on the $\mathrm{CO} 50 \mathrm{CH} 50$ biomixture. Results in Figure 13 addressed that the $\mathrm{CO} 50 \mathrm{CH} 50$ biomixtue also had a promising burning efficiency like $\mathrm{CH} 100$. The $\mathrm{CO} 50 \mathrm{CH} 50$ had the lowest $\mathrm{CO}_{2}$ emission which was $5.8 \%$ and $2.9 \%$ lower than $\mathrm{CO} 100$ and diesel at the full load respectively. Consequently, $\mathrm{CO}_{2}$ emission at high engine loads can be reduced by cottonseed biodiesel and chicken biodiesel blending.

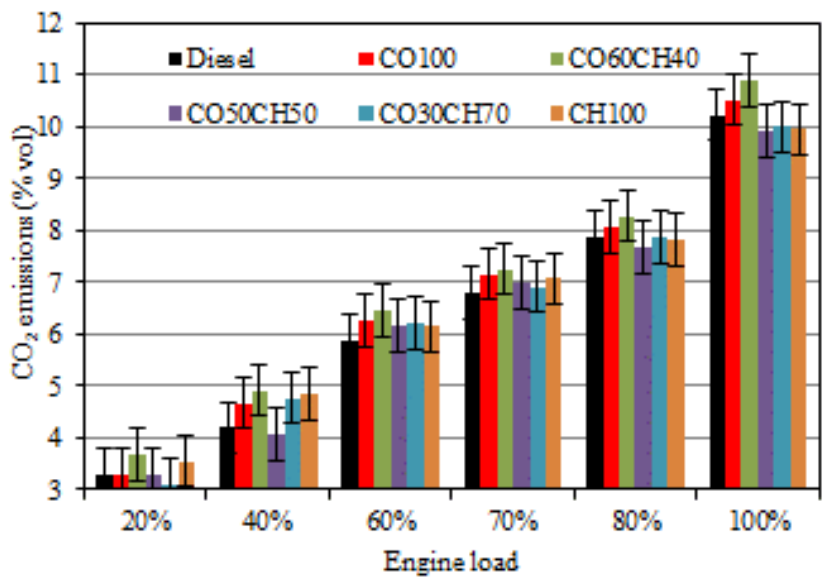

Figure 13. $\mathrm{CO}_{2}$ emissions of the test fuels at different loads.

Figure 14 illustrates the $\mathrm{CO}$ emissions of the test fuels at different engine loads. The $\mathrm{CO} 50 \mathrm{CH} 50$ had a comparable $\mathrm{CO}$ emission with diesel and approximately $15 \%$ lower than both $\mathrm{CO} 100$ and $\mathrm{CH} 100$ at the full engine load. Better burning efficiency of CO50CH50 might have caused this. Unlike CO50CH50, other biomixtures CO60CH40 and $\mathrm{CO} 30 \mathrm{CH} 70$ had around $17 \%$ higher $\mathrm{CO}$ emission than both $\mathrm{CO} 100$ and $\mathrm{CH} 100$. However, in overall $\mathrm{CO} 50 \mathrm{CH} 50$ biomixture proved that blending of cottonseed biodiesel with chicken biodiesel can also reduce $\mathrm{CO}$ emission.

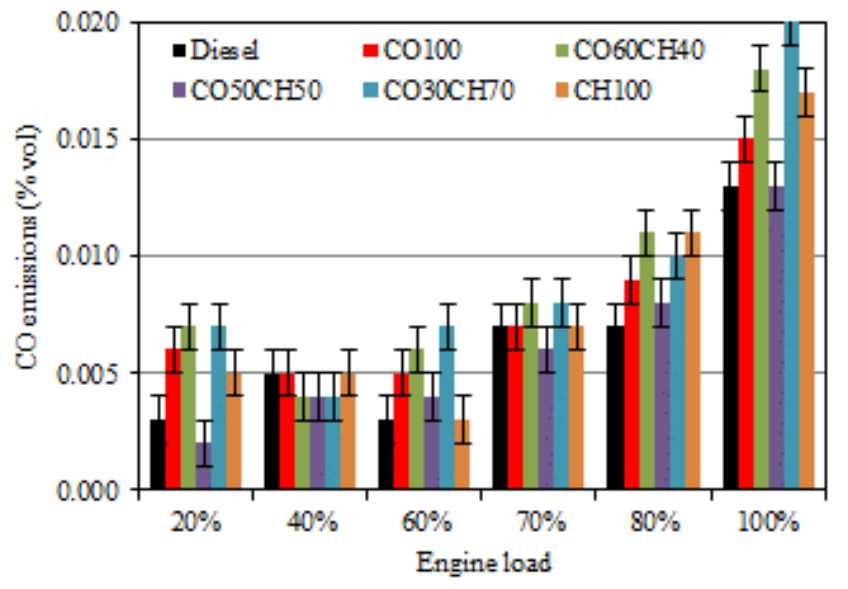

Figure 14. CO emissions of the test fuels at different loads.

NO emissions of the test fuels presented in Figure 15. Although the $\mathrm{NO}_{\mathrm{x}}$ emission was not measured directly, the manufacturer of the equipment stated that $\mathrm{NO}_{\mathrm{x}}$ can be estimated as approximately 1.2 times greater than the measured $\mathrm{NO}$ emission. An increasing trend of NO emission was observed until $80 \%$ engine load, then slightly reduced NO emissions were spotted towards the full engine load. As the engine speed was kept constant at $1500 \mathrm{rpm}$, the air aspiration was the same at every engine load. Among the tested neat biodiesels, CO100 had approximately $3 \%, 4 \%$ and $2 \%$ lower NO emissions than diesel at high engine loads i.e. $70 \%, 80 \%$ and $100 \%$ engine loads respectively. On the other hand, $\mathrm{CH} 100$ had almost the same NO emissions with the diesel. The reduced $\mathrm{NO}$ emissions of $\mathrm{CO} 100$ were in good agreement with the literature [39-41]. Like CO100,

$\mathrm{CO} 60 \mathrm{CH} 40$ also had $6.5 \%$ lower NO emission than the diesel at full engine load. This decrease on NO emission might be explained by the lower in-cylinder pressure and thus the lower combustion temperature because of lower LHV of CO60CH40. However, it has to be concluded that various factors affects the $\mathrm{NO}$ and $\mathrm{NO}_{\mathrm{x}}$ formation which may result in contradictory readings. The ambient conditions, gas residence time of the fuels, fuel spray characteristics, EGR application, oxygen content, physical condition of the experimental equipment, and fluctuations can all affect the $\mathrm{NO}$ and $\mathrm{NO}_{x}$ formation of any fuel, hence it is difficult to figure out the most dominant parameter causing the difference $[43,64-66]$. 


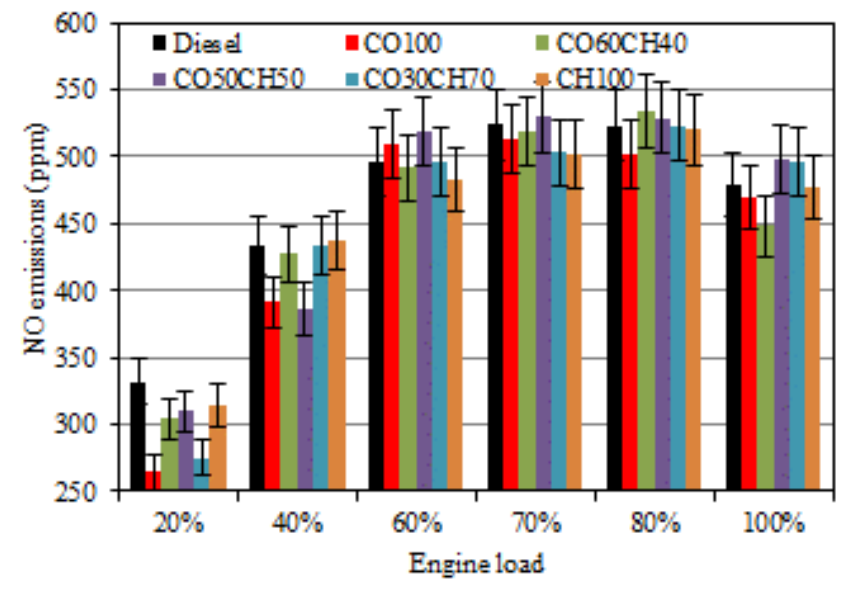

Figure 15. NO emissions of the test fuels at different loads.

\section{Conclusion and Recommendations}

In this study, waste chicken skin rendering fat was selected as a target feedstock due to its high availability and promising fuel properties like cetane number. However, due to the limitations regarding the high viscosity, it did not meet the BS EN 14214 standards. To reduce the viscosity, the chicken biodiesel was blended with cottonseed biodiesel. The blends having 50\% or higher cottonseed biodiesel met the standards. Main conclusions of the biomixtures were;

- $\quad$ BSEC of all the biofuels were comparable with the diesel at the full load condition. However, all biomixtures, CO100, and $\mathrm{CH} 100$ had slightly lower (1.6\%) BTE than diesel.

- The CO50CH50 biomixture had the lowest EGT which was $7.8 \%, 6.9 \%$ and $2.4 \%$ lower than diesel, $\mathrm{CO} 100$ and $\mathrm{CH} 100$ at full engine load, respectively.

- The $\mathrm{CO} 50 \mathrm{CH} 50$ had $4.2 \%$ higher peak in-cylinder pressure than the diesel. Similarly, heat release of the CO50CH50 was $4.4 \%$ higher than the diesel at the early phase of the combustion i.e. between $5^{\circ} \mathrm{CA}$ and $25^{\circ} \mathrm{CA}$ aTDC.

- The $\mathrm{CO} 50 \mathrm{CH} 50$ had the lowest $\mathrm{CO}_{2}$ emission which was $5.8 \%$ and $2.9 \%$ lower than $\mathrm{CO} 100$ and diesel. The $\mathrm{CO}$ emission of CO50CH50 was also found comparable with diesel and approximately $15 \%$ lower than both $\mathrm{CO} 100$ and $\mathrm{CH} 100$ at full engine load. However, $\mathrm{NO}$ emission of CO50CH50 was observed around 6\% higher than diesel. The reduction on $\mathrm{NO}$ emission was reported by the $\mathrm{CO} 60 \mathrm{CH} 40$ by $6.5 \%$ lower than diesel at full engine load.

The biomixtures can be tested under different engine operations such as different engine speeds, transient engine operation, EGR, direct injection or in the presence of after treatment techniques. Moreover, blending of other biodiesels can also be investigated as a future work. This study recommends blending of biodiesels with other biodiesels to enhance or optimise the fuel properties rather than blending with fossil diesel or other additives. Uninvestigated fuel properties such as oxidation stability, metals content, water content etc. should be investigated as a future work to be able to declare that the biomixtures fully complies with the European standards.

\section{References}

1. Ng, J., -H., Teh, J., X., Wong, K., Y., Wu, K., H., et al., “A Techno-Economical and Automotive Emissions Impact Study of Global Biodiesel Usage in Diesel Engines," Journal of the
Society of Automotive Engineers Malaysia 1(2):124-136, 2017, e-ISSN 2550-2239

2. International Energy Agency, "Climate Change,"

https://www.iea.org/topics/climatechange/, accessed Jul. 2018.

3. Twidell, J., T., "Renewable Energy Resources, Third Edition," (Routledge Taylor \& Francis Group: London, 2015), ISBN 9780415584388.

4. Ellabban, O., Abu-Rub, H., and Blaabjerg, F., "Renewable Energy Resources: Current Status, Future Prospects and Their Enabling Technology," Renewable and Sustainable Energy Reviews 39:748-64, 2014, doi:10.1016/j.rser.2014.07.113.

5. Forte, A., Zucaro, A., Faugno, S., Basosi, R., et al., "Carbon Footprint and Fossil Energy Consumption of Bio-Ethanol Fuel Production from Arundo Donax L. Crops on Marginal Lands of Southern Italy," Energy 150:222-35, 2018, doi:10.1016/j.energy.2018.02.030.

6. Krutof, A., and Hawboldt. K., "Blends of Pyrolysis Oil, Petroleum, and Other Bio-Based Fuels: A Review," Renewable and Sustainable Energy Reviews 59:406-19, 2016, doi:10.1016/j.rser.2015.12.304.

7. UK Department for Transport. "Renewable Transport Fuel Obligation Statistics: Period 10 2017/18, Report 3," Statistical Release, $15^{\text {th }}$ April 2017 to $14^{\text {th }}$ April 2018,

https://assets.publishing.service.gov.uk/government/uploads/syst em/uploads/attachment_data/file/704390/rtfo-year-10-report3.pdf., accessed Jul. $20 \overline{1} 8$.

8. ̈̈zener, O., Yüksek, L., Ergenç, A., T., and Özkan, M., "Effects of Soybean Biodiesel on a DI Diesel Engine Performance, Emission and Combustion Characteristics," Fuel 115:875-83, 2014, doi:10.1016/j.fuel.2012.10.081.

9. Srinuanpan, S., Cheirsilp, B., Prasertsan, P., Kato, Y., et al., "Strategies to Increase the Potential Use of Oleaginous Microalgae as Biodiesel Feedstocks: Nutrient Starvations and Cost-Effective Harvesting Process," Renewable Energy 122:507-16, 2018, doi:10.1016/j.renene.2018.01.121.

10. Hossain, A., K., Ouadi, M., Siddiqui, S., U., Yang, Y., et al., "Experimental investigation of performance, emission and combustion characteristics of an indirect injection multi-cylinder $\mathrm{CI}$ engine fuelled by blends of de-inking sludge pyrolysis oil with biodiesel," Fuel 105:135-142, 2013, doi:10.1016/j.fuel.2012.05.007.

11. Wu, Y., Ferns, J., Li, H., and Andrews, G., "Investigation of Combustion and Emission Performance of Hydrogenated Vegetable Oil (HVO) Diesel," SAE Int. J. Fuels Lubr. 10(3): 2017 doi:10.4271/2017-01-2400.

12. Adewale, P., Dumont, M. J., and Ngadi, M., "Recent trends of biodiesel production from animal fat wastes and associated production techniques," Renew. Sustain. Energy Rev. 45:574588, 2015, doi:10.1016/j.rser.2015.02.039.

13. Environment Agency, "Biodiesel: quality protocol," https://www.gov.uk/government/publications/biodiesel-qualityprotocol/biodiesel-quality-protocol\#contents, accessed Apr. 2018.

14. McDougal, T., "Millions of chickens go to landfill in UK each year," https://www.fwi.co.uk/news/environment/millionschickens-go-landfill-uk-year, accessed Jul. 2018.

15. Alptekin, E., and Canakci, M., "Optimization of transesterification for methyl ester production from chicken fat,". Fuel 90(8):2630-2638, 2011, doi:10.1016/j.fuel.2011.03.042.

16. Alptekin, E., and Canakci, M., "Optimization of pretreatment reaction for methyl ester production from chicken fat," Fuel 89(9):4035-4039, 2010, doi:10.1016/j.fuel.2010.04.031.

17. Marulanda, V., F., Anitescu, G., and Tavlarides, L., L., "Investigations on supercritical transesterification of chicken fat for biodiesel production from low-cost lipid feedstocks," J. 
Supercrit. Fluids 54(1):53-60, 2010, doi:10.1016/j.supflu.2010.04.001.

18. Barrios, C., C., Domínguez-Sáez, A., Martín, C., and Álvarez, P., "Effects of animal fat based biodiesel on a TDI diesel engine performance, combustion characteristics and particle number and size distribution emissions," Fuel 117:618-623, 2014 doi:10.1016/j.fuel.2013.09.037.

19. British Standard Institution, "Automotive fuels - Fatty acid methyl esters (FAME) for diesel engines - Requirements and test methods,". Br. Stand. Inst. Bs En 14214:2008+a1:2009, Rev. 2010, 22, ISBN 9780580707810.

20. Kirubakaran, M., and Arul, M., S., V., "A comprehensive review of low cost biodiesel production from waste chicken fat," Renew. Sustain. Energy Rev. 82:390-401, 2018, doi:10.1016/j.rser.2017.09.039.

21. Ashraf, S., Hussain, M., Mumtaz, M., W., and Shuaib, M., "Biodiesel Production by Alkali Catalyzed Transesterification of Chicken and Beef Fats," Int. J. Altern. fuels energy 1(1):14-20, 2017, ISSN:2523-9171

22. Mata, T., M., Cardoso, N., Ornelas, M., Neves, S., et al., "Evaluation of two purification methods of biodiesel from beef tallow, pork lard, and chicken fat," Energy and Fuels 25(10):4756-4762, 2011, doi:10.1021/ef2010207.

23. Mata, T., M., Cardoso, N., Ornelas, M., Neves, S., et al., "Sustainable production of biodiesel from tallow, lard and poultry fat and its quality evaluation," Chem. Eng. Trans. 19:13-18, 2010, doi:10.3303/CET1019003.

24. Bhatti, H., N., Hanif, M., A., Qasim, M., and Ata-ur-Rehman, "Biodiesel production from waste tallow," Fuel 87(1314):2961-2966, 2008, doi:10.1016/j.fuel.2008.04.016.

25. Jagadale, S., S., and Jugulkar, L., M., "Production and Analysis of Chemical Properties of Chicken Fat Based Biodiesel and its various Blends,”. Int. J. Eng. Res. Dev. 1(7):34-37, 2012, ISSN:2278-067X

26. Mata, T., M., Mendes, A., M., Caetano, N., S., and Martins, A., A., "Properties and sustainability of biodiesel from animal fats and fish oil," Chem. Eng. Trans. 38:175-180, 2014, doi:10.3303/CET1438030.

27. Day, C., and Day, G., "Climate change, fossil fuel prices and depletion: The rationale for a falling export tax," Econ. Model. 63:153-160, 2017, doi:10.1016/j.econmod.2017.01.006.

28. Wang, J., Feng, L., Tang, X., Bentley, Y., et al., "The implications of fossil fuel supply constraints on climate change projections: A supply-side analysis,” Futures 86:58-72, 2017, doi:10.1016/j.futures.2016.04.007.

29. Nanthagopal, K., Ashok, B., Varatharajan, V., Anand, V., et al., "Study on the effect of exhaust gas-based fuel preheating device on ethanol-diesel blends operation in a compression ignition engine," Clean Technol. Environ. Policy 19(10):2379-2392, 2017, doi:10.1007/s10098-017-1426-x.

30. Hossain, A., K., and Davies, P., A., "Performance, emission and combustion characteristics of an indirect injection (IDI) multicylinder compression ignition (CI) engine operating on neat jatropha and karanj oils preheated by jacket water," biomass and bioenergy 46:332-342, 2012, doi.10.1016/j.biombioe.2012.08.007

31. Yasin, M., H., M., Yusaf, T., Mamat, R., and Yusop, A., F., "Characterization of a diesel engine operating with a small proportion of methanol as a fuel additive in biodiesel blend," Appl. Energy 114:865-873, 2014, doi.10.1016/j.apenergy.2013.06.012

32. Yilmaz, N., and Atmanli, A., "Experimental assessment of a diesel engine fueled with diesel-biodiesel-1-pentanol blends," Fuel 191:190-197, 2017, doi.10.1016/j.fuel.2016.11.065

33. Imdadul, H., K., Masjuki, H., H., Kalam, M., A., Zulkifli, N., W., M., et al., "Influences of ignition improver additive on ternary (diesel-biodiesel-higher alcohol) blends thermal stability and diesel engine performance," Energy Convers. Manag. 123:252-264, 2016, doi.10.1016/j.enconman.2016.06.040

34. Tosun, E., Yilmaz, A., C., Ozcanli, M., and Aydin, K., "Determination of effects of various alcohol additions into peanut methyl ester on performance and emission characteristics of a compression ignition engine," Fuel 126:38-43, 2014 , doi.10.1016/j.fuel.2014.02.037

35. Alhassan, Y., Kumar, N., Bugaje, I., M., Pali, H., S., et al., "Cosolvents transesterification of cotton seed oil into biodiesel: Effects of reaction conditions on quality of fatty acids methyl esters," Energy Convers. Manag. 84:640-648, 2014, doi:10.1016/j.enconman.2014.04.080.

36. Venkatesan, H., John J., G., and Sivamani, S., "Impact of oxygenated cottonseed biodiesel on combustion, performance and emission parameters in a direct injection CI engine," Int. J. Ambient Energy 0750:1-12, 2017, doi:10.1080/01430750.2017.1381154.

37. Alptekin, E., and Canakci, M., "Characterization of the key fuel properties of methyl ester-diesel fuel blends," Fuel 88(1):75-80, 2009, doi:10.1016/j.fuel.2008.05.023.

38. Ramírez-Verduzco, L., F., Rodríguez-Rodríguez, J., E., and Jaramillo-Jacob, A., D., R., "Predicting cetane number, kinematic viscosity, density and higher heating value of biodiesel from its fatty acid methyl ester composition," Fuel 91(1):102-111, 2012, doi:10.1016/j.fuel.2011.06.070.

39. Aydin, H., and Bayindir, H., "Performance and emission analysis of cottonseed oil methyl ester in a diesel engine," Renew. Energy 35(3):588-592, 2010, doi:10.1016/j.renene.2009.08.009.

40. Karabektas, M., Ergen, G., and Hosoz, M., "The effects of preheated cottonseed oil methyl ester on the performance and exhaust emissions of a diesel engine," Appl. Therm. Eng. 28(1718):2136-2143, 2008, doi:10.1016/j.applthermaleng.2007.12.016.

41. Yucesu, H., S., and Ilkilic, C., "Effect of cotton seed oil methyl ester on the performance and exhaust emission of a diesel engine," Energy Sources Part a-Recovery Util. Environ. Eff. 28(4):389-398, 2006, doi:10.1080/009083190927877.

42. Leevijit, T., Prateepchaikul, G., Maliwan, K.., Mompiboon, P., et al., "Comparative properties and utilization of un-preheated degummed / esterified mixed crude palm oil-diesel blends in an agricultural engine," Renew. Energy. 101: 82-89, 2017, doi:10.1016/j.renene.2016.08.047.

43. Emiroğlu, A., O., Keskin, A., and Şen, M., "Experimental investigation of the effects of turkey rendering fat biodiesel on combustion, performance and exhaust emissions of a diesel engine," Fuel 216:266-273, 2018, doi:10.1016/j.fuel.2017.12.026.

44. Esfahanian, V., Mahdi, M., Gharehghani, A., and Mirsalim, M., "Extending the lean operating range of a premixed charged compression ignition natural gas engine using a pre-chamber," Energy. 119:1181-1194, 2017, doi:10.1016/j.energy.2016.11.071.

45. Kakoee, A., Bakhshan, Y., Motadayen, S., and Gharehghani, A., "An improvement of a lean burning condition of natural gas / diesel RCCI engine with a pre-chamber by using hydrogen," Energy Convers. Manag. 166:489-499. 2018, doi:10.1016/j.enconman.2018.04.063.

46. Yousefi, A., Gharehghani, A., and Birouk, M., "Comparison study on combustion characteristics and emissions of a homogeneous charge compression ignition ( $\mathrm{HCCI}$ ) engine with and without pre-combustion chamber," Energy Convers. Manag. 100:232-241, 2015, doi:10.1016/j.enconman.2015.05.024.

47. Shah, A., Tunestal, P., and Johansson, B., "Effect of PreChamber Volume and Nozzle Diameter on Pre-Chamber Ignition in Heavy Duty Natural Gas Engines," SAE Technical Paper 2015-01-0867. 2015, doi:10.4271/2015-01-0867. 
48. Masera, K., and Hossain, A., K., "Production, Characterisation and Assessment of Biomixture Fuels for Compression Ignition Engine Application,” World Acad. Sci. Engn. Technol. Internat. J. Mech. Aero. Indust. Mecha. Manufact. Engn. 11(12):18571863, 2017, dai:10.1999/1307-6892/10008317.

49. European Standard, "Automotive fuels - Diesel - Requirements and test methods," EN 590:2013, Rev. 2009.

50. Schönborn, A., Ladommatos, N., Williams, J., Allan, R., et al., "The influence of molecular structure of fatty acid monoalkyl esters on diesel combustion," Combust. Flame 156(7):13961412, 2009, doi:10.1016/j.combustflame.2009.03.011.

51. Kurtz, E., and Polonowski, C., J., "The Influence of Fuel Cetane Number on Catalyst Light-Off Operation in a Modern Diesel Engine," SAE Int. J. fuels Lubr. 10(3):664-671, 2017, doi:10.4271/2017-01-9378.

52. M.J. Ramos, M., J., Fernández, C., M., Casas, A., Rodriguez, L. et al., "Influence of fatty acid composition of raw materials on biodiesel properties, "Bioresour. Technol. 100:261-268, 2009, doi:10.1016/j.biortech.2008.06.039

53. Giakoumis, E., G., "A statistical investigation of biodiesel physical and chemical properties, and their correlation with the degree of unsaturation," Renew. Energy 50:858-878, 2013, doi:10.1016/j.renene.2012.07.040.

54. Schober, S., and Mittelbach, M., "Iodine value and biodiesel: Is limitation still appropriate?," Lipid Technol. 19(12):281-284, 2007, doi:10.1002/lite.200700091.

55. Predojević, Z., J., "The production of biodiesel from waste frying oils: A comparison of different purification steps," Fuel 87(17-18):3522-3528, 2008, doi:10.1016/j.fuel.2008.07.003.

56. Benjumea, P., Agudelo, J., R., and Agudelo, A., F., "Effect of the degree of unsaturation of biodiesel fuels on engine performance, combustion characteristics, and emissions," Energy and Fuels. 25:77-85, 2011, doi:10.1021/ef101096x.

57. Sanjid, A., Kalam, M., A., Masjuki, H., H., Varman, M., et al., "Performance and emission of multi-cylinder diesel engine using biodiesel blends obtained from mixed inedible feedstocks," J. Clean. Prod. 112:4114-4122, 2016 doi:10.1016/j.jclepro.2015.07.154

58. Reddy, T., R., Krishna, M., V., S., M., Reddy, C., K., and Murthy, P., V., K., "Comparative performance of ceramic coated diesel engine with mohr oil in crude and biodiesel form," Int. J. Eng. Adv. Technol. 2(3):588-596, 2012, ISSN:2249-8958

59. Krishna, M., V., S., M., Prakash, T., O., Ushasri, P., Janardhan, N., et al., "Experimental investigations on direct injection diesel engine with ceramic coated combustion chamber with carbureted alcohols and crude jatropha oil," Renew. Sustain. Energy Rev.53:606-628, 2016, doi.org/10.1016/j.rser.2015.09.011.

60. Dhamodaran, G., Krishnan, R., Pochareddy, Y., K., Pyarelal, H., M., et al., "A comparative study of combustion, emission, and performance characteristics of rice-bran-, neem-, and cottonseed-oil biodiesels with varying degree of unsaturation," Fuel 187:296-305, 2017, doi:10.1016/j.fuel.2016.09.062.

61. Awad, S., Loubar, K., and Tazerout, M., "Experimental investigation on the combustion, performance and pollutant emissions of biodiesel from animal fat residues on a direct injection diesel engine," Energy 69:826-836, 2014, doi:10.1016/j.energy.2014.03.078.

62. Hossain, A., K., Serrano, C., Brammer, J., B., Omran, A., et al., "Combustion of fuel blends containing digestate pyrolysis oil in a multi-cylinder compression ignition engine," Fuel 171, 18-28, 2016, doi:10.1016/j.fuel.2015.12.012.

63. Kumar, A., and Subramanian, K., A., "Control of greenhouse gas emissions (CO2, CH4and N2O) of a biodiesel (B100) fueled automotive diesel engine using increased compression ratio," Appl. Therm. Eng. 127:95-105, 2017, doi:10.1016/j.applthermaleng.2017.08.015.
64. Ulusoy, Y., Arslan, R., Tekin, Y., Sürmen, A., et al., "Investigation of performance and emission characteristics of waste cooking oil as biodiesel in a diesel engine," Pet. Sci. 15(2):396-404, 2018, doi:10.1007/s12182-018-0225-2.

65. Ramalingam, S., and Rajendran, S., "NOx Emission Reduction in Annona Biodiesel Engine by Means of Antioxidant Additives," SAE Int. J. Fuels Lubr. 10(3):652-663, doi:10.4271/2017-01-9377.

66. Omari, A., Pischinger, S., Nuottimäki, J., and Honkanen, M., "Improving Engine Efficiency and Emission Reduction Potential of HVO by Fuel-Specific Engine Calibration in Modern Passenger Car Diesel Applications Om Parkash Bhardwaj and Bastian Holderbaum," SAE Int. J. Fuels Lubr. 10(3):756-767, 2017, doi:10.4271/2017-01-2295.

\section{Contact Information}

Kemal Masera. Email address: maserak@aston.ac.uk. Address: Sustainable Environment Research Group, Aston University, Birmingham, UK, B4 7ET.

A.K. Hossain. Phone: 44(0)121 204 3041. Email address: a.k.hossain@aston.ac.uk. Address: Sustainable Environment Research Group, Aston University, Birmingham, UK, B4 7ET.

\section{Acknowledgments}

The authors acknowledge the PhD studentship fund provided by the School of Engineering and Applied Science, Aston University, UK. Support from Kistler is also highly acknowledged.

\section{Definitions/Abbreviations}

$\begin{array}{ll}\text { aTDC } & \text { After top dead centre } \\ \text { BSEC } & \begin{array}{l}\text { Brake specific energy } \\ \text { consumption }\end{array}\end{array}$

BS EN $14214 \quad$ British \& European biodiesel standards

BSFC

Brake specific fuel consumption

BTE

Brake thermal efficiency

CA

Crank angle

CD

Combustion duration

CH100

Chicken biodiesel

CN

Cetane number

CO

Carbon monoxide

$\mathrm{CO}_{2}$

Carbon dioxide

CO100

Cottonseed biodiesel

СО80СH20

eed biodiesel blended with $20 \%$ chicken 
biodiesel

$60 \%$ cottonseed biodiesel

blended with $40 \%$ chicken

biodiesel

$50 \%$ cottonseed biodiesel

blended with $50 \%$ chicken biodiesel

$30 \%$ cottonseed biodiesel blended with $70 \%$ chicken biodiesel

CO30CH70

СО10СH90

EGR

EGT

EOC

FFA

GC

HCCI

ID

KOH
$10 \%$ cottonseed biodiesel blended with $90 \%$ chicken biodiesel

Exhaust gas recirculation

Exhaust gas temperature

End of combustion

Free Fatty Acid

Gas chromatography

Homogeneous charge compression ignition

Ignition delay

Potassium hydroxide
$\mathrm{NO}_{x}$

PCCI

Lower heating value

Mass spectrum

Nitric oxide

Nitrogen oxides

Premixed charge compression ignition

RCCI

Reactivity controlled compression ignition

SCR

Selective catalytic reduction

SOC

Start of combustion

SOI

Start of injection

UK

United Kingdom 